\title{
Technology of concentrated training as one of ways to optimization students' basketball trainings
}

\author{
Lavrin H.Z.
}

Ternopil Volodymyr Hnatiuk National Pedagogical University

\begin{abstract}
Purpose:

to find out effectiveness of concentrated training technology in students' basketball trainings.

Material:

55 students participated in experiment. The research was being conducted during one academic year. Skillfulness in basketball techniques was determined with the help of tests' complex. We assessed: basketball techniques fulfillment and their quantitative parameters (quickness of dribbling, passes, movements and accuracy of hitting in basket). Every student was offered to fulfill 7 tests, by results of which we assessed their techniques. Every test was assessed by 12-points' scale.

Results: $\quad$ We proved that for students, who did not practiced basketball trainings beforehand, it is possible to master basketball material. For saving time it was envisaged to master minimal quantity of techniques, required and sufficient for playing basketball. It was found that the technology of concentrated basketball training does not influence on students' somatic health.

Conclusions: Criterion of the mentioned technology's effectiveness was the level of students' mastering of basketball techniques and their basketball playing in general. It is noted that basketball training increases effectiveness of mastering of other sport disciplines. Systemic practicing of basketball resulted in students' success in envisaged by curriculum light athletic and gymnastic.

Keywords: training technology, basketball, game techniques, students.
\end{abstract}

\section{Introduction}

Basketball is one of effective students' physical education means. Basketball facilitates harmonious development, complex and comprehensive influence on organism, health strengthening $[11,20,22,32]$. Great variety of basketball movements facilitates nervous system and muscular-skeletal apparatus's strengthening, metabilism improvement, all organism's systems' functioning [12, 26, 30]. However, actualstudents' skills in basketball leave much to be disired. The reason of such situation is basketball's insufficient training in school years. It is connected with the follosing: poor sport facilities (absence of gyms, basketball backboards, balls) in schools; imperfect methodic of physical culture classes at schools; in some schools teachers prefer training of other sport games. All these result in absence of most students' skills in basketball. It should be noted that physical education program for higher educational establishments envisages course of basketball [8, 35].

As on to day there are many methodic recommendations and other information sources for basketball trainings. Though, mainly they are oriented on sportsmen's training in groups of sportsmanship [12, 18, 33, 34]. Basketball specialists elucidate in their works questions of history, techniques and tactic of the game. Besides, they study methodic of sport training, organization of competitions. At the same time technology of students basketball trainings has not become a subject of separate research.

Different approaches to training have been developed for students' basketball trainings $[4,5,8,19]$. The method of concentrated training is in their basis. Such technology stipulates mastering of minimal, but sufficient quantity of techniques for bilateral game. The technology can be realized by compact training during pre-set period $[3,10]$. All these ensure for students to participate in bilateral games after the shortest possible time and satisfies

\footnotetext{
(c) Lavrin H.Z., 2017

doi:10.15561/20755279.2017.0205
}

students' demand to play and compete instead of training techniques during long time. In basketball trainings authors recommend to fulfill the following procedures: determine minimal scope of basketball techniques and tactic, which would be sufficient for bilateral game; work out microtechnologies of every technique's mastering as well as for independent mastering of every technique; work out meso-technology of tactic training and game training; determine the sequence of techniques' training and their place in curriculum during academic year as well as their connection with other techniques and parts f curriculum; ensure the correspondence of academic material volume to duration of training lesson; form system of control over students' independent work [5, 6, 7, 15]. Such approaches are also used in other kinds of sports. In particular for physical loads' optimization in Judo [14, 23, 24] and students' physical education [17, 21, 27, 28], control of students' motor fitness [29, 31] and schoolchildren's [16, $17,25]$. It permits to improve students' health and avoid excessive physical loads.

So, relevance of the present research is conditioned by basketball importance as physical education mean. It should also be added that working out of technology of students' concentrated training requires certain substantiation.

The purpose of the research: optimization of basketball training technique in technology of students' concentrated training.

The purpose determines the following tasks of the research:

Characterize influence of the worked out technology on students' physical condition and physical fitness. Assess the level of students' mastering of basketball techniques and basketball in the whole.

\section{Material and methods}

Participants: in pedagogic experiment $551^{\text {st }}$ year students of pedagogic university participated. The 
students were divided into control group (CG) (12 boys and 15 girls) and experimental group (EG) (14 boys and 14 girls). All participants were informed about aims and conditions of experiment and gave their consent.

Organization of the research: the research was being fulfilled during one academic year. At the beginning of experiment we determined groups' homogenity by physical fitness and physical condition indicators. Trainings in EG and CG had similar and distinctive features. Similar features: in both groups trainings were conducted in compliance with acting program, except sport games' part. Distinctive features: CG students trained basketball in school. EG students did not train basketball in school. EG studentds trained basketball by concentrated technology in experiment.

In total 72 hours were stipulated by curriculum per academic year $\left(36 \mathrm{hrs}-1^{\text {st }}\right.$ semester and $36 \mathrm{hrs}-2^{\text {nd }}$ semester). EG students trained only basketball during 20 hours in $1^{\text {st }}$ semester; the rest time (16 hours) they mastered volleyball material. CG students trained volleyball during planned 10 hours, basketball (10 hours) and football (6 hours). In mastering other parts of academic program there were no distinctions [13].

In EG, during time assigned for sport games, students concentrated trained minimum of basketball techniques, which permit to ply bilateral game. In the process of experimental technology implementation in EG we followed the rule: training of one holistic game instead of separate techniques of one or different games. In this time, in CG students mastered basketball techniques and trained other sport games. At the end of academic year we assessed mastering of basketball techniques and playing basketball [5, 9]. Besides, we registered and compared indicators of both group students' physical condition and physical fitness.

In experiment we used: physiological methods (pulse measuring for Robinson's index and Ruffiet' index; spirometry - for life index; dynamometry - for power index; express assessment of physical health (by G.L. Apanasenko); pedagogic observation. Testing was used for assessment of basketball techniques' mastering level [5]. The techniques (catching and passes of ball, dribbling, stops and throws) were assessed by 12-points' scale. If technique was fulfilled with mistakes, from 12 we deducted points for mistakes [5]. Quickness and efficiency of basketball techniques; fulfillment were also assessed by 12 points' scale. Physical fitness was assessed with tests for physical fitness $(60 \mathrm{~m}, 1500 \mathrm{~m}, 4 \times 9 \mathrm{~m}$ run; quantity of torso risings in sitting position and pressing ups in lying position; long jump; flexibility) [1].

Effectiveness of students' concentrated basketball training technology was evaluated with the help of pedagogic experiment. Criterion of the mentioned technology's effectiveness was level of students' mastering of basketball techniques and their ability to play basketball in general. Besides, we determined indicators of students' physical fitness and somatic health.

Physical fitness level was determined in both groups at the beginning of experiment. At the beginning of experiment we found no noticeable distinctions in physical fitness of EG and CG students ( $\mathrm{p}>0.05)$.

Statistical analysis: the results of the research were processed with variation statistic methods, implying finding of mean arithmetic (M), arithmetic error (m), mean square deviation $(\sigma)$ and confidence of differences by Student's t-test (p).

\section{Results}

Application of basketball training's experimental technology positively influenced on EG students' physical fitness. After experiment EG boys demonstrated better results in dexterity and endurance $(\mathrm{P}<0.01)$. EG students' speed-power indicators significantly improved, comparing CG students' indicators.

Before experiment most of CG students (54\%) and EG students (51\%) had average level of physical fitness. Part of CG and EG students had physical fitness higher than average: accordingly 39\% (girls - 57\%, boys $21,5 \%$ ) and $29.5 \%$ (girls $27 \%$, boys $33 \%$ ). $15 \%$ of EG students had physical fitness level below average (girls $13 \%$, boys $17 \%$ ) and $7 \%$ of CG (girls $0 \%$, boys $14 \%$ ). Analysis of physical fitness after experiment showed that in EG quantity of students with physical fitness low level decreased (by 4\%), below average (by 4\%) and average (by 19\%). Quantity of EG students with physical fitness above average increased by $22 \%$; with high level - by $4 \%$. In CG we did not register any changes in physical fitness level. In CG 14\% of girls came from level above average to average level.

In some tests (shuttle run $4 \times 9 \mathrm{~m}$ and 1500 meters' run) we observed substantial differences between CG and EG students after experiment. In the rest of EG indicators we observed tendency to their increment. Accordingly, percentage of students' quantity in different groups of physical fitness also changed. It was evidence that on individual level physical fitness changed to the better.

One of criteria of experimental technology's effectiveness assessment was its influence on students' health. Somatic health was determined by methodic of G.A. Apanasenko [1]. By results of morphological functional indicators no noticeable differences were detected between $\mathrm{CG}$ and $\mathrm{EG}$ students $(\mathrm{P}>0.05)$.

The received indicators (body height, body mass, vital capacity of lungs, hand dynamometry, heart beats rate, blood pressure, life and power indices, Robinson's and Rouffiet's indices) were used for determination of somatic health by methodic of G.A. Apanasenko. It should be noted that after concentrated basketball training technology's realization there were found no statistically confident changes $(\mathrm{P}>0.05)$ in functional tests' results in CG and EG. It permits to say that the offered technology influences on students' health in the same way as traditional trainings methods (see table 1).

As far as the main task of experimental technology's working out and realization was to train students to basketball, one of main criteria of students' ability to play basketball assessment was determination of their basketball techniques' mastery. 
Table 1. Indicators of students' physical health before and after experiment

\begin{tabular}{|c|c|c|c|c|c|c|c|c|c|c|}
\hline \multirow{2}{*}{$\begin{array}{l}\text { Functional tests } \\
\text { Sex }\end{array}$} & & & \multicolumn{2}{|c|}{ Life index, $\mathrm{ml} / \mathrm{kg}$} & \multicolumn{2}{|c|}{ Power index,\% } & \multicolumn{2}{|c|}{$\begin{array}{l}\text { Robinson's } \\
\text { index, conv.un. }\end{array}$} & \multicolumn{2}{|c|}{$\begin{array}{l}\text { Rouffiet's } \\
\text { index, conv.un. }\end{array}$} \\
\hline & & & Boys & Girls & Boys & Girls & Boys & Girls & Boys & Girls \\
\hline \multirow{6}{*}{$\begin{array}{l}\text { After } \\
\text { experiment }\end{array}$} & \multirow{2}{*}{ CG } & $M_{x}$ & 52 & 54 & 49 & 53 & 89 & 96 & 11 & 12 \\
\hline & & $\pm m$ & 2.5 & 2.3 & 2.3 & 1.8 & 3 & 4.5 & 0.7 & 0.6 \\
\hline & \multirow{2}{*}{ EG } & $M_{x}$ & 56 & 50 & 55 & 50 & 94 & 90 & 10 & 11 \\
\hline & & $\pm \hat{m}$ & 2.2 & 2.3 & 3 & 0.8 & 2.6 & 2.5 & 0.6 & 0.5 \\
\hline & $\mathrm{t}$ & & 1.2 & 1.1 & 1.6 & 1.4 & 1.2 & 1 & 1.5 & 0.8 \\
\hline & $P$ & & $>0.05$ & $>0.05$ & $>0.05$ & $>0.05$ & $>0.05$ & $>0.05$ & $>0.05$ & $>0.05$ \\
\hline
\end{tabular}

Table 2. Students' mastery of basketball basic techniques

\begin{tabular}{|c|c|c|c|c|c|c|c|}
\hline Techniques & $\begin{array}{l}\text { Sex } \\
\mathrm{n}\end{array}$ & $\begin{array}{l}\text { CG } \\
M_{x}\end{array}$ & $\pm m$ & $\begin{array}{l}\text { EG } \\
M_{x}\end{array}$ & $\pm m$ & $\mathbf{t}$ & $\mathbf{P}$ \\
\hline \multirow{2}{*}{$\begin{array}{l}\text { Ball's catching and passes with two hands from } \\
\text { chest, points }\end{array}$} & Boys & 8.1 & 0.3 & 8.3 & 0.5 & 0.3 & $p>0.05$ \\
\hline & Girls & 6.4 & 0.3 & 8.6 & 0.5 & 3.8 & $p<0.001$ \\
\hline \multirow{2}{*}{ One arm's pass from shoulder, points } & Boys & 7.07 & 0.26 & 8.42 & 0.49 & 2.43 & $p<0.05$ \\
\hline & Girls & 6.14 & 0.33 & 8.2 & 0.38 & 4.11 & $p<0.001$ \\
\hline \multirow{2}{*}{ Dribbling, points } & Boys & 7.21 & 0.38 & 8.33 & 0.37 & 2.12 & $p<0.05$ \\
\hline & Girls & 6.93 & 0.5 & 8 & 0.53 & 1.47 & $p>0.05$ \\
\hline \multirow{2}{*}{ Stops after two steps and turns, points } & Boys & 6 & 0.4 & 7.3 & 0.5 & 2.3 & $p<0.05$ \\
\hline & Girls & 5.4 & 0.4 & 7.7 & 0.4 & 4.4 & $p<0.001$ \\
\hline \multirow[t]{2}{*}{ Two arms' throw from chest, points } & Boys & 7.36 & 0.34 & 7.83 & 0.47 & 0.82 & $p>0.05$ \\
\hline & Girls & 6.86 & 0.33 & 8.67 & 0.49 & 3.06 & $p<0.01$ \\
\hline \multirow[t]{2}{*}{ One arm's throw from shoulder, points } & Boys & 6.29 & 0.37 & 8.83 & 0.41 & 4.62 & $p<0.001$ \\
\hline & Girls & 6.07 & 0.34 & 7.66 & 0.37 & 3.17 & $p<0.01$ \\
\hline \multirow{2}{*}{ Throw from double step, points } & Boys & 6.07 & 0.41 & 8.75 & 0.7 & 3.28 & $p<0.01$ \\
\hline & Girls & 5.71 & 0.28 & 8.87 & 0.47 & 5.82 & $p<0.001$ \\
\hline
\end{tabular}

Notes: CG - control group, EG - experimental group.

Table 3. Quickness and efficiency of basketball techniques' fulfillment

\begin{tabular}{|c|c|c|c|c|c|c|c|}
\hline Techniques & $\begin{array}{l}\text { Sex } \\
\mathrm{n}\end{array}$ & $\begin{array}{l}\text { CG } \\
M_{x}\end{array}$ & $\pm m$ & $\begin{array}{l}\text { EG } \\
M_{x}\end{array}$ & $\pm m$ & $\mathbf{t}$ & $\mathbf{P}$ \\
\hline \multirow{2}{*}{$\begin{array}{l}20 \text { accurate passes by two hands from chest to } \\
\text { the wall at } 1.5 \mathrm{~m} \text { distance }\end{array}$} & Boys & 5,2 & 0,43 & 6,45 & 0,68 & 1,91 & $p<0,1$ \\
\hline & Girls & 4,86 & 0,52 & 6,4 & 0,56 & 2,01 & $p<0,1$ \\
\hline \multirow{2}{*}{$\begin{array}{l}20 \text { accurate passes by one arm from shoulder to } \\
\text { the wall at distance } 2 \text { meters }\end{array}$} & Boys & 6,5 & 0,69 & 6,6 & 0,69 & 0,08 & $p>0,05$ \\
\hline & Girls & 4,5 & 0,79 & 6,53 & 0,56 & 2,09 & $p<0,05$ \\
\hline \multirow{2}{*}{ Left hand and right hand dribbling $(2 \times 18 \mathrm{~m})$} & Boys & 5,14 & 0,59 & 6,7 & 0,82 & 1,4 & $p>0,05$ \\
\hline & Girls & 6,29 & 0,55 & 6,67 & 0,63 & 0,45 & $p>0,05$ \\
\hline \multirow{2}{*}{$\begin{array}{l}\text { Ball dribbling ( } 24 \mathrm{~m} \text { ) by farther hand bypassing } \\
\text { stands (every } 6 \text { meters) }\end{array}$} & Boys & 5,92 & 0,69 & 6,58 & 0,64 & 0,69 & $p>0,05$ \\
\hline & Girls & 4,64 & 0,67 & 6,33 & 0,53 & 1,96 & $p<0,1$ \\
\hline \multirow{2}{*}{$\begin{array}{l}20 \times 5 \mathrm{~m} \text { moving by side step in basketball player's } \\
\text { stance }\end{array}$} & Boys & 6,4 & 0,6 & 6,42 & 0,63 & 0,01 & $p>0,05$ \\
\hline & Girls & 6,71 & 0,44 & 6,6 & 0,51 & $-0,16$ & $p>0,05$ \\
\hline \multirow{2}{*}{$\begin{array}{l}\text { Quantity of hits in the basket from } 15 \text { attempts } \\
\text { ( } 5 \text { attempts from the left, } 5 \text { from the right and } \\
5 \text { from the front) at distance of } 1.5 \text { meters (for } \\
\text { girls) and } 2 \text { meters (for boys) }\end{array}$} & Boys & 6,57 & 0,5 & 8,25 & 0,59 & 2,17 & $p<0,05$ \\
\hline & Girls & 5,64 & 0,44 & 7,53 & 0,44 & 3,04 & $p<0,001$ \\
\hline \multirow{2}{*}{$\begin{array}{l}\text { Quantity of hits in the basket from } 7 \text { attempts } \\
\text { after dribbling by side step }\end{array}$} & Boys & 4,9 & 0,7 & 7,5 & 0,83 & 2,38 & $p<0,05$ \\
\hline & Girls & 4,21 & 0,58 & 6,4 & 0,77 & 2,25 & $p<0,05$ \\
\hline
\end{tabular}

The level of basketball techniques' mastery was registered with the help of tests' complex for assessment quantitative parameters of basketball techniques, fulfilled by students (quickness of dribbling, passes, movements, hitting basket). 7 testes were offered to every student. Each test was assessed by 12 points' scale. 12 points were given 
for test's fulfillment without mistakes. If any mistakes, some points were deducted from 12 for the mistakes.

As far as at the beginning of experiment experimental group students had no skills in basketball techniques, testing results of control and experimental groups were compared at the end of experiment.

Results of tests for students' mastery of basketball basic techniques show the advantage of EG students, comparing with CG (see table 2) In $50 \%$ of tests EG boys demonstrated statistically confident better results than $\mathrm{CG}$ boys. EG girls were better than CG girls in $78.6 \%$ of tests $(p<0.05)$. EG students also demonstrated better results in quickness and efficiency of basketball techniques' fulfillment (see table 3 ).

In bilateral basketball game EG students' actions were better than the same of CG. For assessment of students' skill in playing basketball we used the record of observations [9]. It was found that CG students gained $5.4 \pm 0.6$ points per one game, while EG students $-7.8 \pm 0.5$ points $(p<0.05)$. Results of EG and CG matches showed advantage of EG both by results of the game and by mass character of basketball techniques' mastery. In EG all students participated in game. In CG not all students demonstrated ability to play basketball.

Between CG and EG groups 3 bilateral games were conducted, separately between girls' teams and between boys' teams (two times, 12 minutes each). It was found that EG boys won 2 games from 3 (with insignificant difference in scores: 34:28; 28:33; 38:32). Girls won 3 games from 3 with high difference in scores $(24: 6 ; 32: 10$; 42:12)

\section{Discussion}

Results of our study proved the data [8, 10, 11], that basketball practicing facilitates development and improvement of players' physical qualities. Our researches showed that to the largest extent they influence positively on endurance, dexterity and speed-power qualities. The worked out technology did nor impact noticeably on students' somatic health. Average health index of EG and CG boys and girls corresponded to low health level that is one more prove of modern youth's low health level.

Results of students' functional tests proved the data of other reseraches [20, 22]: basketball trainings positively influence on students' health. We also proved the fact that for assessement of students' ability to play basketball it is purposeful to use records of observations [26, 30]. Objectiveness of assessment results by the records of observations is confirmed by results of games, carried out between the tested groups.

Scientists [2, 5, 32] note that basketball trainings improve effectiveness of mastering of other curriculum disciplines. Our results prove these data. Systemic practicing of basketball means resulted in students' successful mastering the envisaged by curriculum material of light athletic and gymnastic.

The novelty is the data about specific aspects of students' basketball training. We proved that it is possible to train basketball those students, who did not practice basketball beforehand. For saving time it was stipulated to master minimal quantity of techniques, required and sufficient for basketball playing. The received testing results show efficiency of the implemented technology of students' basketball training.

Results of testing techniques' mastery and the game itself witness that it is possible to successfully apply concentrated method of basketball trainings. It was determined that this technology permits to sustain and improve general physical qualities in the process of students' physical education. This, experimentally tested technology of basketball training can be applied in educational establishments, which seek for optimization of educational process.

\section{Conclusions}

Implementation of concentrated basketball training technology improved physical fitness of EG students. After experiment EG boys showed better dexterity and endurance indicators $(p<0.01)$ as well as speed-power indicators. The worked out technology did not noticeably influence on somatic health of the participants.

EG students mastered basketball techniques better than CG. EG boys demonstrated statistically confidently better results in $50 \%$ of tests. CG girls in $78.6 \%$ of tests yielded EG girls $(p<0.05)$. Results of games between CG and EG teams show better mastery of material by EG students.

The prospects of the research: the present work does not open completely all aspects of effectiveness of students' basketball training technology. In the future we intend to test its effectiveness and influence on students' cognitive processes and field of vision.

\section{Conflict of interests}

The author declares that there is no conflict of interests. 


\section{References}

1. Volkov VM, Tereshchenko O. Kontrol' $i$ ocinka fizichnoi pidgotovlenosti students'koi molodi [Control and assessment of students' physical fitness], Kiev: Nora-Print; 2006. (in Ukrainian)

2. Lavrin GZ. Basketbol ta jogo riznovidi - odin iz shliakhiv zaluchennia riznikh verstv naselennia do masovoi fizichnoi kul'turi [Basketball and its kinds - one of ways of different population strata involvement in mass physical culture]. $V$ Mizhnarodna naukovo-praktichna konferenciia “Aktual'ni problemi rozvitku sirotu dlia vsikh: dosvid, dosiagnennia, tendencii" [V International scientific-practical conference "Current problems of sports for all development: experience, achievements, tendencies”], Ternopil; 2016. P.91-95. (in Ukrainian)

3. Lavrin GZ. Proceduri formuvannia tekhnologii navchannia uchniv gri v basketbol [Procedures of formation of pupils' basketball training technology]. Teoriia ta metodika fizichnogo vikhovannia, 2008;10(48):35-37. (in Ukrainian)

4. Lavrin GZ. Tekhnologiia navchannia vedenniu m’iacha v basketboli [Technology of dribbling training in basketball]. Teoriia ta metodika fizichnogo vikhovannia, 2015;1:26-30. (in Ukrainian)

5. Lavrin GZ, Rebrina AA. Tekhnologiia navchannia studentiv gri v basketbol [Technology of students' basketball training], Khmelnitsky: KNU; 2015. (in Ukrainian)

6. Lavrin GZ. Tekhnologiia navchannia uchniv gri v basketbol [Technology of pupils' basketball training], Ternopil: SMT "Taipei"; 2013. (in Ukrainian)

7. Maksimiv G. Tekhnologiia igrovoi pidgotovki pid chas navchannia uchniv gri v basketbol [Technology of preparation for game in pupils' basketball training], Teoriia ta metodika fizichnogo vikhovannia, 2007;10(36):26-28. (in Ukrainian)

8. Maksimiv G. Tekhnologiia navchannia basketbolu studentiv nespecializovanikh fakul'tetiv [Technology of basketball training for not specialized faculties' students]. III Vseukrains'ka naukova konferenciia "Problemi i perspektivi nauk $v$ umovakh globalizacii” [III All-Ukrainian scientific conference "Problems and prospects of sciences in conditions of globalization"],Ternopil: TNPU; 2007. P.170172. (in Ukrainian)

9. Maksimiv GZ. Tekhnologiia navchannia basketbolu uchniv zagal'noosvitn'oi shkoli [Technology of basketball training for comprehensive schools' pupils], Ternopil: TNPU; 2005. (in Ukrainian)

10.Maksimiv G. Tekhnologiia navchannia prijomiv gri v basketbol uchniv zagal'noosvitn'oi shkoli [Technology of basketball techniques' training for comprehensive schools' pupils], Moloda sportivna nauka Ukraini, 2006;10(1); 150155. (in Ukrainian)

11.Poplavs'kij LIu. Basketbol [Basketball], Kiev: Olympic Literature; 2004. (in Russian)

12.Zhelezniak IuD, Portnov IuM. Sportivnye igry [Sport games], Moscow: Academy; 2001. (in Russian)

13.Raievs'kij RT, Tret'iakov MO, Kanishevs'kij SM. Fizichne vikhovannia [Physical education], Kiev: MONU; 2003. (in Ukrainian)

14. Arziutov G, Iermakov S, Bartik P, Nosko M, Cynarski WJ. The use of didactic laws in the teaching of the physical elements involved in judo techniques. Ido Movement for Culture, 2016;16(4):21-30. doi:10.14589/ido.16.4.4

15.Badric M, Prskalo I, Matijevic M. Primary School Pupils' Free Time Activities. Croatian Journal of EducationHrvatski Casopis Za Odgoj I Obrazovanje. 2015;17(2):299331.
16.Bliznevsky AA, Kudryavtsev MD, Iermakov SS, Jagiello W. Formation of active-effective attitude of 12-13 years' judo athletes to sports functioning in competition period. Archives of Budo. 2016;12:101-15.

17.Bodnar IR, Andres AS. Tests and standards for expresscontrol of physical fitness and health of middle school age pupils. Pedagogics, psychology, medical-biological problems of physical training and sports, 2016; 20(4): 11-16. doi:10.15561/18189172.2016.0402

18. Coutinho DAM, Reis SGN, Goncalves BSV, Silva A, Sampaio AJD, Leite NMC. Manipulating the number of players and targets in team sports. Small-Sided Games during Physical Education classes. Revista De Psicologia Del Deporte. 2016;25(1):169-77.

19.Darnis F, Lafont L. Cooperative learning and dyadic interactions: two modes of knowledge construction in socioconstructivist settings for team-sport teaching. Physical Education and Sport Pedagogy. 2015;20(5):459-73.

20.Evans AB, Bright JL, Brown LJ. Non-disabled secondary school children's lived experiences of a wheelchair basketball programme delivered in the East of England. Sport Education and Society. 2015;20(6):741-61

21.Godoy-Cumillaf AER, Carcamo-Araneda CR, HermosillaRodriguez FP, Oyarzun-Ruiz JP, Viveros-Herrera JFJ. Nutritional status by anthropometric and biochemical parameters of college basketball players. Nutricion Hospitalaria. 2015;32(6):2828-31.

22.Harvey S, Smith ML, Song Y, Robertson D, Brown R, Smith LR. Gender and School-Level Differences in Students' Moderate and Vigorous Physical Activity Levels When Taught Basketball Through the Tactical Games Model. Journal of Teaching in Physical Education. 2016;35(4):34957.

23.Iermakov SS, Arziutov GN, Jagiello W. Quick training of students to judo techniques. Archives of Budo. 2016;12:1524

24.Iermakov SS, Podrigalo LV, Jagiello W. Hand-grip strength as an indicator for predicting the success in martial arts athletes. Archives of Budo. 2016;12:179-86.

25.Khudolii OM, Ivashchenko OV, Iermakov SS, Rumba OG. Computer simulation of Junior gymnasts' training process. Science of Gymnastics Journal, 2016;8(3):215-228.

26.Kozina ZL, Iermakov SS, Kadutskaya LA, Sobyanin FI, Krzeminski M, Sobko IN, Ryepko OA. Comparative characteristic of correlation between pulse subjective indicators of girl students' and school girls' reaction to physical load. Physical Education of Students. 2016;20(4):2434. doi:10.15561/20755279.2016.0403

27.Kudryavtsev MD, Kopylov YuA, Kuzmin VA, Ionova OM, Yermakova TS. Personality oriented system of strengthening of students' physical, psychic and social-moral health. Physical education of students, 2016; 20(3): 43-52. doi:10.15561/20755279.2016.0308

28.Lentillon-Kaestner V, Patelli G. Effects of Grouping Forms, Student Gender and Ability Level on the Pleasure Experienced in Physical Education. Journal of Teaching in Physical Education. 2016;35(3):251-62.

29.Mouratidis A, Lens W. Adolescents' psychological functioning at school and in sports: the role of future time perspective and domain-specific and situation-specific self-determined motivation. Journal of Social and Clinical Psychology. 2015;34(8):643-73.

30.Nishan Singh Deol, Davinder Singh. A comparative analysis of flow state in basketball performance: a psychological probe. Pedagogics, psychology, medical-biological problems 
of physical training and sports, 2016; 20(1): 47-51. doi:10.15561/18189172.2016.0107

31.Osipov AYu, Kudryavtsev MD, Gruzinky VI, Kramida IE, Iermakov SS. Means of optimal body mass control and obesity prophylaxis among students. Physical education of students, 2017; 21(1): 40-45. doi:10.15561/20755279.2017.0107

32.Otero-Sabortdo FM, Lluch AC, Gonzalez-Jurado JA. Student precision and reliability of the team sport assessment in basketball: a primary education case study. South African Journal for Research in Sport Physical Education and Recreation. 2015;37(2):83-94.
33.Reuker S. The knowledge-based reasoning of physical education teachers: A comparison between groups with different expertise. European Physical Education Review. 2017;23(1):3-24.

34.Sari I. Satisfaction of basic psychological needs and goal orientation in young athletes: a test of basic psychological needs theory. Kinesiology. 2015;47(2):159-68.

35.Triki M, Koubaa A, Masmoudi L, Fellmann N, Tabka Z. Prevalence and risk factors of low back pain among undergraduate students of a sports and physical education institute in Tunisia. Libyan Journal of Medicine. 2015;10.

Information about the author:

Lavrin H.Z.; http://orcid.org/0000-0001-6750-8421; maximiv@bigmir.net; Ternopil Volodymyr Hnatiuk National Pedagogical University; 2 Maxyma Kryvonosa str., Ternopil, 46027, Ukraine.

Cite this article as: Lavrin HZ. Technology of concentrated training as one of ways to optimization students' basketball trainings. Physical education of students, 2017;2:78-83. doi:10.15561/20755279.2017.0205

The electronic version of this article is the complete one and can be found online at: http://www.sportedu.org.ua/index.php/PES/issue/archive

This is an Open Access article distributed under the terms of the Creative Commons Attribution License, which permits unrestricted use, distribution, and reproduction in any medium, provided the original work is properly cited (http://creativecommons.org/licenses/by/4.0/deed.en).

Received: 26.02.2017

Accepted: 09.03.2017; Published: 04.04.2017 